\title{
A NEW SPECIES OF CYCLOGRAPSUS (DECAPODA, GRAPSIDAE) AND NOTES ON FIVE OTHERS FROM THE PACIFIC OCEAN
}

\author{
BY \\ D. J. G. GRIFFIN \\ Australian Museum, Sydney, Australia
}

The crabs belonging to the genus Cyclograpsus $\mathrm{H}$. Milne Edwards are typical intertidal grapsids of the subfamily Sesarminae but lack the pronounced hairy reticulation on the pterygostomian regions characteristically found in species of Sesarma and their allies. In a recent revision of the four species found in Australia and New Zealand (Campbell \& Griffin, 1966) it was considered that there were 13 species in the Indo-Pacific excluding species confined to the Americas; a key to these was given. It was also shown that $C$. punctatus is not a circum-subantarctic species but is found in South Africa and possibly South America.

Further examination of collections from the Pacific, Chile and the island of Juan Fernandez (off the coast of Chile), and of the literature, has shown firstly that a further species, $C$. beccarii, described from western New Guinea by Nobili (1899), was overlooked by Campbell \& Griffin; secondly, that an undescribed species is present on Santa Cruz, south of the Solomon Islands in the south west Pacific Ocean; thirdly, that the specimen recorded by Ward (1939) as C. minutus Lucas from Penrhyn Island in the central Pacific is conspecific with the new species from Santa Cruz; fourthly, that $C$. lavauxi, previously regarded as confined to New Zealand, is present on Juan Fernandez; and fifthly, that C. minutus Jacquinot is conspecific with $C$. cinereus and not with $C$. punctatus as previously considered by Rathbun (1918) and subsequent authors.

In this paper the new species is described and morphological features of taxonomic importance, not previously mentioned in the literature, are described in Cyclograpsus cinereus, C. escondidensis (a species confined to central western America) and $C$. integer. The material from Juan Fernandez referred here to $C$. lavauxi is discussed and evidence is presented to show that $C$. punctatus is probably not present in Chile.

Terminology and the system of measurements follow that used by Campbell \& Griffin (1966). Carapace length and carapace width are abbreviated as c.l. and c.w. respectively.

Cyclograpsus sanctaecrucis n. sp. (figs. 1; 2a, b, e; 3a, b; 4a, b, g)

Cyclograpsus minutus - Ward, 1939: 14. Not Cyclograpsus minutus Jacquinot, in Jacquinot \& Lucas, 1853 ( $=$ C. cinereus Dana). 


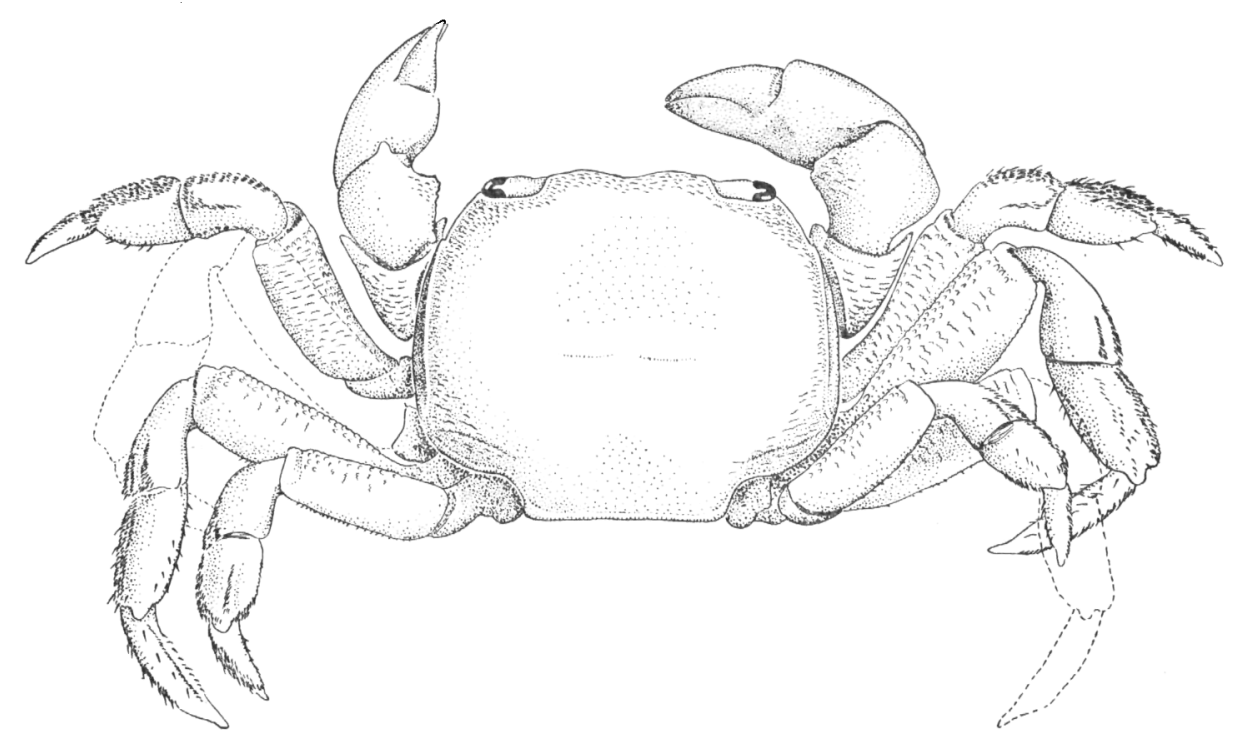

Fig. 1. Cyclograpsus sanctaecrucis n. sp., holotype, dorsal aspect.

Holotype. - Male, c.l. $7.2 \mathrm{~mm}$, c.w. $8.7 \mathrm{~mm}$, Carlisle Bay, Santa Cruz, Pacific Ocean, A. A. Livingstone and E. le G. Troughton, July 20, 1926 (reg. no. P. 9034); spirit specimen with carpus and following segments of third right ambulatory leg and merus and following segments of second left ambulatory leg missing, specimen otherwise intact. - Australian Museum, Sydney.

Paratypes. - Male, c.1. $6.7 \mathrm{~mm}$, c.w. $8.0 \mathrm{~mm}$, same locality data as for holotype (reg. no. P. 15411) - Australian Museum, Sydney. Female (ovig.), c.l. $5.8 \mathrm{~mm}$, c.w. $7.1 \mathrm{~mm}$, Penrhyn Island (Tongareva), Pacific Ocean, September 24, 1936; Second Templeton Crocker Expedition to Pacific Ocean on "Zaca"; det. Melbourne Ward as "Cyclograpsus minutus Lucas" (reg. no. 7510) American Museum of Natural History, New York.

Description. - Carapace hardly broader than long, lateral margins convex anteriorly, subparallel posteriorly; widest close to half carapace width from front. Surface close to anterolateral and frontal margins appearing granular, covered with short, minute, transverse, irregularly crenulate ridges; similar, but longer, sparser, interrupted, ridges extending obliquely posteromedially from posterolateral margins, a long weakly cristate ridge parallel to these extending inwards from margin just forward of posterolateral angle of carapace; a narrow ridge, microscopically granulate, except along posterior margin, extending around margin of carapace; surface otherwise smooth. Regions obscure, only gastrocardiac groove at all prominent. Lateral margins with a minute indentation or interruption about $1 / 5$ carapace length from front. Front fairly strongly deflexed, frontal margin barely visible from above, divided by a very shallow groove into two weakly convex lobes. Orbits with posterior border minutely crenulate, directed obliquely posterolaterally, smoothly rounded medially and laterally, junction with frontal margin smoothly rounded, external orbital tooth short, acute, not nearly reaching level of front. Suborbital ridge with three small, narrow lobules towards medial end and two broader ones laterally but mostly smooth and uninterrupted. 
Chelipeds with merus trigonal, bearing on outer surface low, transverse, minutely crenulate ridges strongest towards dorsal and ventrolateral crests, medial and ventral surfaces mostly smooth except for few small tubercles. Carpus smooth except dorsomedially where surface bears short, transverse, crenulate ridges; inner angle with a few very small spinules. Chela of male longer than deep, smooth on both inner and outer surfaces, ventral edge weakly concave at junction of palm and fixed finger, palm deepest midway along. Fingers widely gaping for their entire length, inwardly strongly toothed, edges almost straight, teeth of dactyl irregular in size and spacing, those of fixed finger regular, about seven in number, slightly smaller proximally than elsewhere, those midway along the largest.

Ambulatory legs long, second the longest (1.5 times carapace width), not particularly robust, compressed, meri trigonal, surfaces with transverse, interrupted crenulate ridges on posterior surfaces particularly strong towards blunt dorsal crest which bears a narrow band of small tubercles which continues down close to, and parallel with, distal edge; dactyli slender. Short, stout hairs on all legs on meri dorsally in a fringe overlying distal edge and on dorsal surfaces and edges of carpi and following segments which also bear scattered longer stouter hairs. First leg with carpus bearing hairs, except on proximal quarter, in three broad rows dorsally, anteriorly, and posteriorly distally; propodus with broad band of hairs dorsally, a more slender, longitudinal line along middle of anterior surface joined to dorsal band by similarly slender, transverse rows of hairs via an ill-defined, intermediate, longitudinal row midway between dorsal band and central row; two short, broad bands of hairs ventrally; dactyl with broad dorsal band of hairs and three other slender longitudinal rows, one each on anterior, ventral and posterior surfaces. Second leg with hairs arranged as on first leg. Third leg with dorsal bands of hairs well developed, otherwise naked except for four rows of hairs on dactyl. Last leg with dorsal band of hairs on carpus for distal half weakly divided into three rows; propodus with dorsal band narrow proximally, broad distally and extending around distal edge dorsally and a short band on distal third of ventral surface; dactyl with broad dorsal band and three other slender rows as on other legs.

Tufts of hairs projecting between bases of first and second and second and third legs arising from anterior and posterior surfaces of bases of second leg, posterior surface of first and anterior surface of third legs.

Sternum naked except for very narrow band of short hairs around anterior margin of abdominal fossa and narrow transverse band across first sternal segment opposite bases of chelipeds.

Male abdomen widest near base of third segment, following segments tapering to base of sixth which is laterally weakly convex, seventh segment not much longer than wide, laterally tapering and distally rounded.

Colour. - In spirit, creamy white on body and appendages, hairs pale to russet.

Remarks. - Except in the presence of a lateral notch on the carapace, this species most closely resembles $C$. integer. $C$. sanctaecrucis differs from that species 
in having the lateral margins of the carapace less strongly divergent backwards, the suborbital ridge scarcely inteirupted, the male abdomen of a different shape and the ambulatory propodi more slender and finally, the horny terminal process on the male first pleopod is shorter in the present species than in $C$. integer. In the key provided by Campbell \& Griffin (1966), C. sanctaecrucis would appear near $C$. longipes from which it differs in several features, notably the possession of only one lateral notch on the carapace, less divergent lateral margins and weakly developed epigastric (or postfrontal) lobes. From the other Cyclograpsus species which have the carapace laterally notched, the new species differs in having only one notch laterally and in the granulation and arrangement of hairs on the ambulatories, $C$. intermedius having hairs on the dactyli only.

There is a photograph of the type locality of this species - Carlisle Bay, Santa Cruz - in Australian Museum Magazine, 3 (3): 78 (July-September 1927).

\section{Cyclograpsus beccarii Nobili, 1899}

Cyclograpsus beccarii Nobili, 1899: 41-42.

Remarks. - This species was overlooked by Campbell \& Griffin (1966) in their compilation of a key to Indo-west Pacific species of the genus. In that key this species would probably come out at couplet 4; according to Nobili's description it could be distinguished from both $C$. intermedius and $C$. incisus in that there are two distinct teeth on the lateral margin, the first larger than the orbital. angle, these two followed by four small notches; the carapace is strongly convex from front to back and the surface is minutely punctate and the front is vertically inclined with the lower margin projecting; the suborbital border is composed of rather large granules; the superior borders of the ambulatory legs are rugose denticulate; and finally, the merus of the third maxilliped is firmly fixed on the ischium and the "internal angle of the fifth joint forms with them an angle rather stronger and quite different from Cyclograpsus". Nobili considered, in view of this last feature, that $C$. beccarii should be placed in a new generic division. This is further supported by the strongly dentate nature of the lateral borders of the carapace.

C. beccarii was originally described from Dorei (= Manokwari), near the north-western tip of West Irian (New Guinea) and was based on two males and one female. The specimens were supposedly deposited in the Museo Civico di Storia Naturale, Genoa, Italy, but they cannot now be found in the collections of that institution (Prof. E. Tortonese, pers. comm.).

\section{Cyclograpsus cinereus Dana, 1851 (figs. 2f; 3c, d; 4c, d)}

Cyclograpsus cinereus - Rathbun, 1918: 327-328, pl. 98; Garth, 1957: 99-101; Edmondson, 1959: 187, 188, figs. 19a-b; Campbell \& Griffin, 1966: 140 (in key).

Cyclograpsus minutus Jacquinot, 1852: pl. 16 fig. 8; Jacquinot, 1853: 75. Not Cyclograpsus minutus

- Ward, 1939: 14 ( = C. sunctaecrucis n. sp.). 


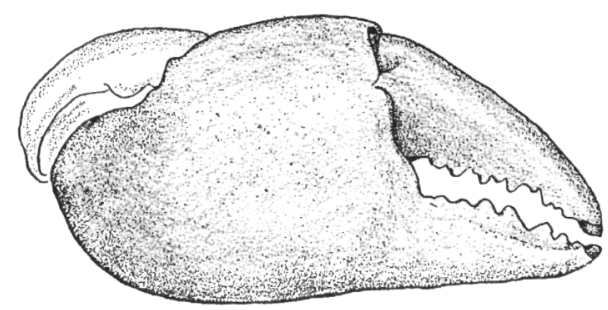

a

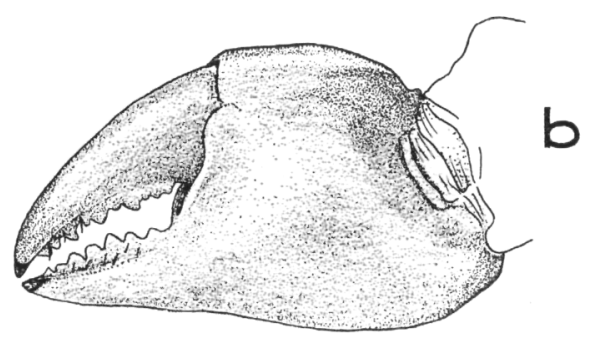

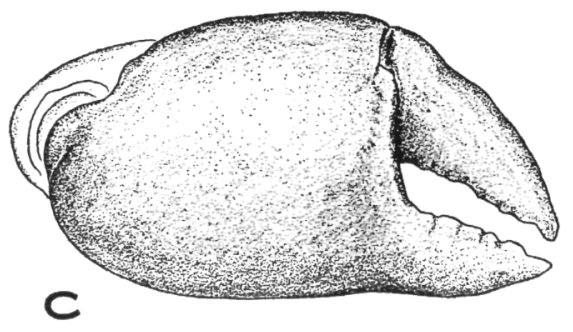

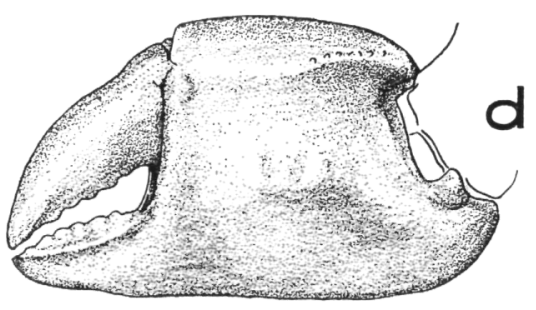

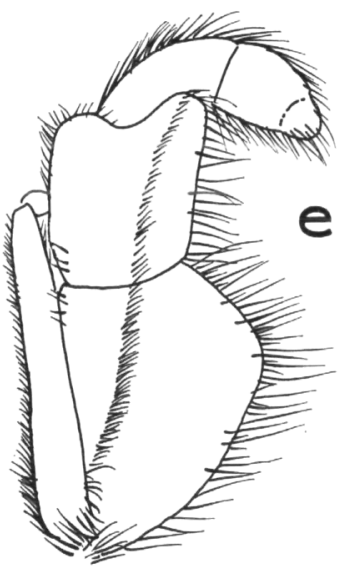
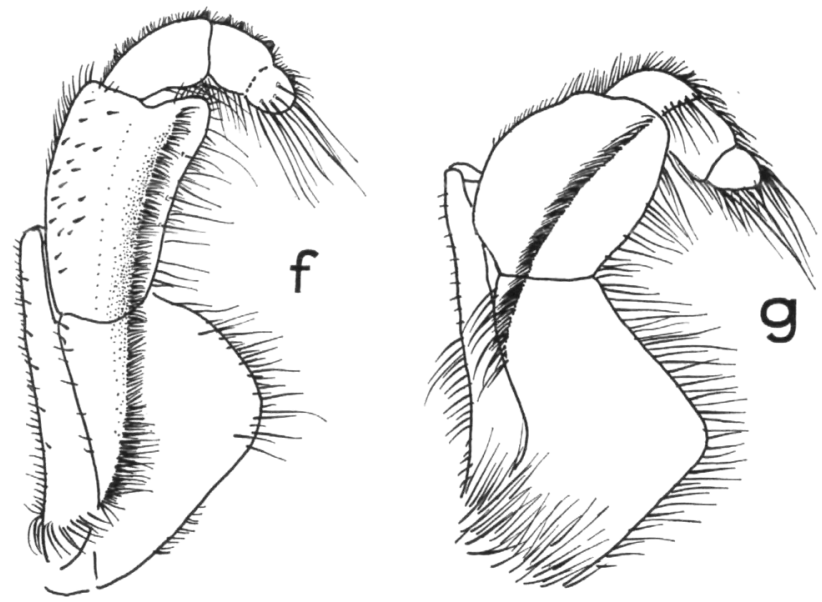

Fig. 2. a-d, right chela of male ( $a, c$, outer face; $b$, d, inner face); e-g, right third maxillipec. a, b, e. Cyclograpsus sanctaecrucis n. sp., holotype; c, d, C. integer H. Milne Edwards, c.w. $9.2 \mathrm{~mm}$. Wake Island; f, C. cinereus Dana, male, c.w. $9.2 \mathrm{~mm}$, Antofagasta; g, C. escondidensis Rathbun, male, c.w. $8.8 \mathrm{~mm}$, Gonzaga Bay, Mexico.

Holotype of C. minutus. - Male, c.l. $9 \mathrm{~mm}$, c.w. $10.5 \mathrm{~mm}$, Talcahueno, Chile (sic) (fide Garth, 1957). The specimen is dry with all legs missing except the right cheliped. - Muséum National d'Histoire Naturelle, Paris.

Material examined. - 1 male, c.w. $11.2 \mathrm{~mm}, 1$ female, c.w. $11.0 \mathrm{~mm}$, E. of Viejas Island, Independencia Bay, Peru, January 13, 1935, shore, coll. Velero III; det. J. S. Garth as C. cinereus. - Allan Hancock Foundation, Los Angeles. 
38 males, 24 females, c.w. $5.3-9.2 \mathrm{~mm}$, Antofagasta, Chile. - Centro Universitario Zona Norte Laboratoria de Biologia, Antofagasta.

3 males, 3 females, c.w. 10.3-14.5 mm, Lota, Chile, littoral, W. L. Schmitt, January 16, 1927 (reg. no. 70863 (part)). - United States National Museum, Washington.

6 males 3 females (1 ovig.), c.w. 8.9-15.2 mm, ovig. female, $11.0 \mathrm{~mm}$, "Central Chile from Province of Aconcagua to Province of Talca, exch. from C. E. Porter" (reg. no. 45520). United States National Museum, Washington. This series includes the males figured by Rathbun (1918).

Description. - This species has been briefly described and figured by Rathbun (1918) and by Edmondson (1959). The following features have not previously been described in detail. The male first pleopod is here figured for the first time.

Carapace surface anteriorly and anterolaterally sometimes weakly punctate, granular only near external orbital angle; a weak, minutely granular, oblique ridge extending medially from lateral margin close to, and parallel with, posterolateral margin above base of fourth leg. Front steeply deflexed, barely visible in dorsal view, margin very weakly bilobate or quadrilobate. Suborbital ridge comprising about 10 granules, large medially but diminishing in size laterally and fading into a low ridge; a fringe of short hairs between ridge and orbit.

Ambulatory legs all almost devoid of hairs; meri in all with transverse, minutely crenulate ridges dorsally, antero- and posteroventral edges granular; surface otherwise sparsely punctate and minutely granular dorsally on carpi and propodi. First leg with short, stout hairs more or less in groups dorsally above distal margin of propodus and extending down distal edge on anterior surface to about halfway along ventral surface; several long hairs arising singly from distal $2 / 3$ of ventral surface; dactyl with six longitudinal rows of short, stout hairs, rows broadest and densest dorsally but still distinct, a few long hairs arising from ventral surface. Second and third legs with short, stout hairs scattered along ventral half of propodi and in six distinct rows on dactyli as in first leg; scattered long hairs arising from ventral surface of both segments of both legs. Fourth leg with short, broad, dense, distal patch of short, stout hairs dorsally and sparse patch ventrally towards distal edge of propodus; dactyl with six rows of short, stout hairs, dorsal ones broad and sometimes hardly distinct, ventral one faint.

A tuft of hairs between first and second ambulatory legs; only sparse short hairs between other legs.

Sternum naked except for inconspicuous scattered hairs and dense pubescence on first sternite in front of and usually around lateral margin of abdominal fossa.

Remarks. - Comparison of photographs of the holotype of C. minutus, kindly supplied by Mme. Danièle Guinot, with previous descriptions of $C$. cinereus and the specimens listed above, shows that Jacquinot's species is conspecific with Dana's and not with $C$. punctatus $\mathrm{H}$. Milne Edwards, as stated by Rathbun (1918: 328), Garth (1957: 101) and by Campbell \& Griffin (1966: 142). The holotype of $C$. minutus agrees with the above-mentioned specimens of $C$. cinereus in carapace shape, shape of the front in ventral view, prominent grooving of the third maxillipeds and, most noticeably, in the shape of the male abdomen, with 
the sixth segment extremely wide in relation to the seventh which is long and narrow with a small median tubercle proximally. Finally, the male first pleopods are extremely stout and distally broad, with a strong tuft of long hairs. The main distinguishing feature of $C$. cinereus is the shape of the abdomen in the male, rather than the absence of distal "teeth" on the ambulatory meri. Rathbun (1918: 327) states that the carapace is smooth anteriorly whereas it is sometimes weakly punctate. The merus of the third maxilliped is very narrow, as noted by Rathbun, and almost straight sided; in this feature $C$. cinereus resembles $C$. punctatus (see Campbell \& Griffin 1966, fig. 4 A (not 3 A)) although in C. cinereus the medial margin of the ischium is very convex. There is considerable variation in the pattern of felting of the ambulatories - whilst the hairs are confined to the distal edge on both first and last legs they may be isolated or in groups, sometimes moderately dense and sometimes sparse.

Distribution. - Pacific South America from Ancon, Peru to Calbuco, Chile, Panama (extralimital) (Garth, 1957), ? Hawaii (Edmondson, 1959).

\section{Cyclograpsus escondidensis Rathbun, 1933 (figs. 2g; 3e, f; 4e, f)}

Cyclograpsus escondidensis Rathbun, in Glassell, 1933: 336, pl. 23.

Material examined. - 1 male, c.w. $8.8 \mathrm{~mm}$, Willard Point, Gonzaga Bay, Gulf of California, Mexico, March 23, 1937, Velero III, det. J. S. Garth as Cyclograpsus escondidensis. - Allan Hancock Foundation, Los Angeles.

Description. - The carapace, chelipeds, ambulatory legs and abdomen were briefly described and figured by Rathbun; the following features, not mentioned by Rathbun, are taxonomically important; ambulatories and male first pleopod are figured here.

Suborbital ridge composed of numerous minute granules interspersed with short hairs.

Chelipeds with inner surface of palm of chela with scattered granules around middle and towards base of fixed finger, also towards dorsal edge in three to four longitudinal rows.

Ambulatory legs with all carpi bearing four longitudinal, minutely tuberculate ridges, one mid-dorsal, one centrally on anterior surface and two on posterior surface in dorsal half. First leg with short hairs in dense patch distally on dorsal surface of carpus, covering whole of anterior surface of propodus, posterior surface of propodus sparsely covered; hairs also arranged in six longitudinal rows on dactyl; scattered long hairs arising from amongst short hairs towards dorsal and ventral edges of propodus and dactyl. Second and third legs with hairs arranged as on first leg. Fourth leg with scattered short hairs and a few long hairs over whole of posterior surface of propodus, in a very small distal tuft on dorsal surface of carpus and in six rows on dactyl; anterior surface of propodus naked.

Remarks. - This species was omitted from the key to Indo-west Pacific species of Cyclograpsus given by Campbell \& Griffin (1966) as it is confined to central 

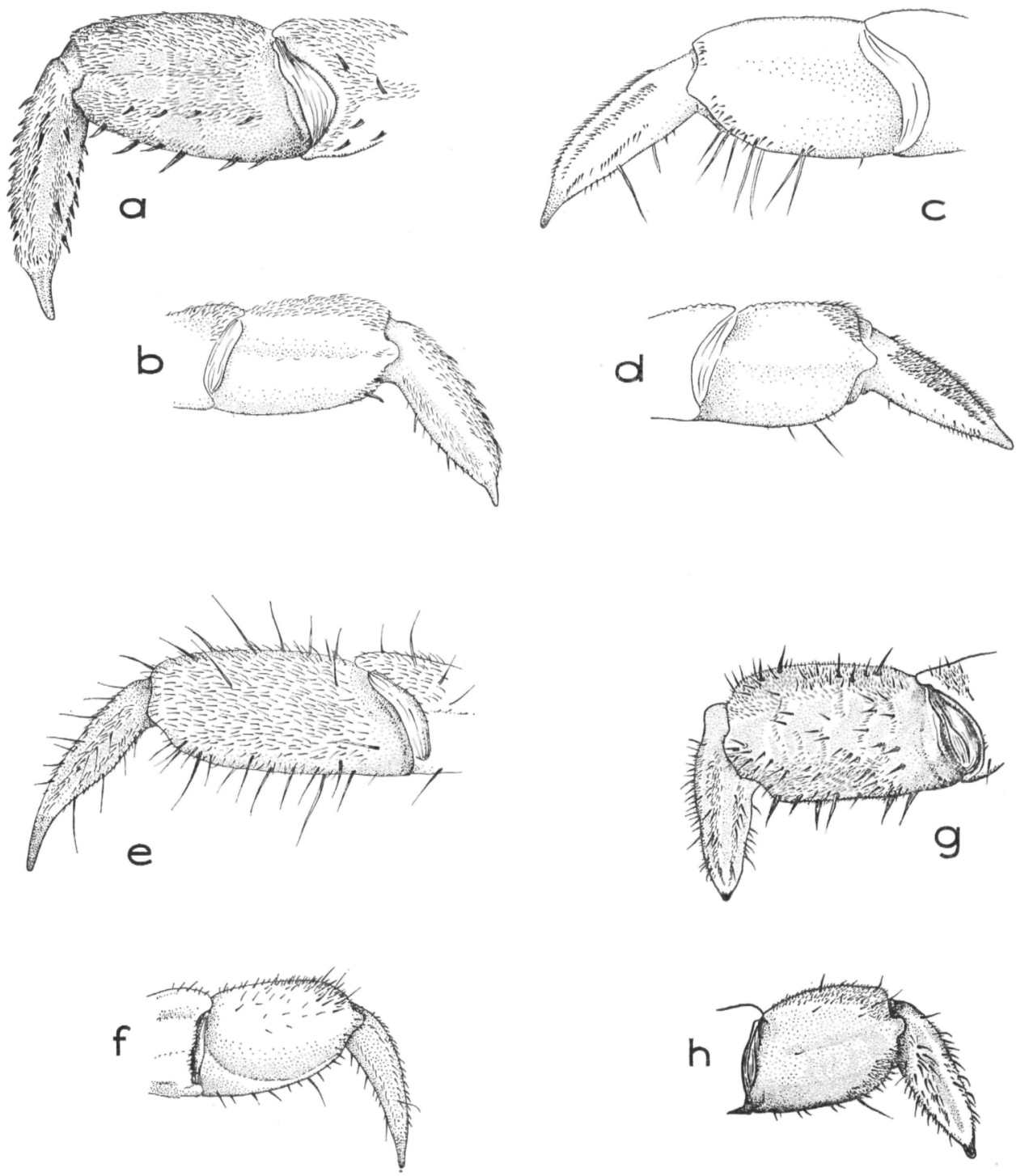

Fig. 3. a, c, e, g, anterior face of propodus and dactyl of right first ambulatory leg; b, d, f, h, posterior face of propodus and dactyl of right fourth ambulatory leg. a, b, C. sanctaecrucis n. sp.; c, d, C. cinereus Dana; e, f, C. escondidensis Rathbun; g, h, C. integer $\mathrm{H}$. Milne Edwards. Specimens illustrated same as in fig. 2 .

western America. Within the key just mentioned this species comes out at couplet 7 along with $C$. integer $\mathrm{H}$. Milne Edwards and $C$. benshawi Rathbun. From both these species $C$. escondidensis is distinguished by the form of the suborbital border; from $C$. integer to which it is most closely allied it differs in having the front almost straight and agrees in having the sides of the abdomen in the male almost 
straight; the pattern of hairs on the ambulatories is similar in the two. From all other species of Cyclograpsus, $C$. escondidensis is at once distinguished by the greatly broadened ambulatory meri, the pattern of felting on the distal segments of the legs and by the form of the pleopod in the male, which resembles that of Metasesarma species more than it does that of its congeners (see Forest \& Guinot, 1961: 161, fig. $174-M$. rousseauxi).

Distribution. - Known only from Puerto Escondido (type locality) and Gonzaga Bay (present material) in the Gulf of California, Mexico.

\section{Cyclograpsus integer $H$. Milne Edwards, 1837 (figs. 2c, d; 3g, h; 4h)}

Cyclograpsus integer - Rathbun, 1918: 326-7, pl. 97 figs. 1, 2; Monod, 1956: 451, figs. 609-612; Forest \& Guinot, 1961: 160, 162; Crosnier, 1965: 78-79, fig. 129; Hartnoll 1965: 114, 115, 137-8; Campbell \& Griffin, 1966: 149 (in key).

Cyclograpsus audouinii - Edmondson, 1925: 56. Not Cyclograpsus audouinii H. Milne Edwards, 1837.

Material examined. - 2 males, 2 females, c.w. 8.8-10.3 mm, Wake Island, Pacific Ocean, C. H. Edmondson, July 1923, det. C. H. Edmondson as Cyclograpsus audouinii (cat. no. 1400). Bernice P. Bishop Museum, Honolulu.

Description. - This species has previously been briefly described and figured by De Man (1897 as C. parvulus), and by Rathbun (1918), Monod (1956), Forest \& Guinot (1961) and Crosnier (1965). The ambulatory legs and male abdomen have not been previously described in detail or figured.

Ambulatory legs with all meri bearing low, irregularly crenulate, transverse ridges best developed dorsally, surfaces also with punctae. First leg with short hairs in a distal dorsal tuft on the carpus, covering most of the propodus, forming a distally broad, longitudinal band dorsally, a very broad band on the ventral surface except for a short naked portion proximally and irregularly broad and narrow bands on the anterior surface linking the dorsal and ventral bands, posterior surface naked except dorsally and ventrally, and in six broad longitudinal bands on the dactyl; scattered long hairs arising singly or in groups of 2 to 6 from amongst the short hairs on all segments. Second and third legs with hairs arranged as on first leg except for scattered hairs on posterior surface of propodus. Fourth leg with short hairs on propodus in a narrow dorsal patch on distal half and ventral quarter and in six rows on dactyl; scattered long hairs singly or in groups as on other legs over whole of propodus, on dactyl and distally on carpus.

Tufts of long hairs arising from bases of second and third legs to fill gap between them ventrally.

Male abdomen widest at base of first segment, laterally tapering to about midway along sixth segment and then narrowing suddenly; seventh segment subtriangular, apically rounded. Second segment very short, remaining segments subequal in length except sixth which is about twice length of others, basal width $1 \frac{1}{2}$ times its length. First segment with a long low transverse ridge near its origin. 
Remarks. - The synonymy of this very widespread species is now quite complicated. The included names are Cyclograpsus occidentalis A. Milne Edwards, 1878, Cyclograpsus parvulus De Man, 1896, Epigrapsus politus sensu Nobili, 1907 (non E. politus Heller) (see Forest \& Guinot, 1961; Crosnier, 1965), Cyclograpsus punctatus sensu Lenz, 1910 and now C. audouinii sensu Edmondson, 1925.

Edmondson based his record from Wake Island on 38 specimens and the present series of four are from that sample. They agree in every important feature with previous descriptions and illustrations of $C$. integer by Rathbun (1918), Forest \& Guinot (1961) and Crosnier (1965). The distinguishing features of this species are the trilobate suborbital ridge and form of the first pleopod in the male (see Forest \& Guinot, 1961). In this last feature there is a similarity to C. escondidensis except that the terminal horny process is much shorter in the present species. In the arrangement of hairs on the ambulatories there is a resemblance to $C$. sanctaecrucis.

Distribution. - Western Atlantic from southern Florida to Brazil including the Bahamas and Bermuda; eastern Atlantic (West Africa) from Senegal and Cape Verde Islands to Angola; western Indian Ocean at Madagascar; Indonesia (Atjeh, Flores Sea); northern west Pacific (Wake Island and Marshall Islands); and eastern central Pacific (Tuamotus). The species is not known in the eastern Pacific east of the Tuamotus.

Of the species of crabs listed by Forest \& Guinot (1962) C. integer is the only one which occurs in the Atlantic and western Pacific but is absent from the eastern Pacific. It is perhaps significant that the only Pacific central American Cyclograpsus species, $C$. escondidensis, is more similar to $C$. integer than to any other species of the genus.

\section{Cyclograpsus lavauxi H. Milne Edwards, 1837}

Cyclograpsus lavauxi - Campbell \& Griffin, 1966: 143-145, text-fig. 4B (not 3B), 5B, pl. 20 fig. 4 , pl. 23 fig. 4 (synon.).

Material examined. - 1 male, c.w. $16.2 \mathrm{~mm}, 1$ female, c.w. $16.0 \mathrm{~mm}$, Cumberland Bay, Mas a Tierra Island, Juan Fernandez Islands, Chile, December 12, 1965, cobble beach, coll. Janet Haig and Cesar Acleto, "Anton Bruun" Cruise 12 - Allan Hancock Foundation, Los Angeles.

2 males, c.w. 8.9 and 9.6 mm, Juan Fernandez, leg. C. Bock, February 1922, det. J. S. Garth as Cyclograpsus punctatus (reg. no. K5884 (part)). — Zoologisches Museum, Hamburg.

1 female, c.w. $9.6 \mathrm{~mm}$, "along boulder covered beach to left of "factory" ", Juan Fernandez, W. L. Schmitt, December 8, 1926; det. M. J. Rathbun as Cyclograpsus lavauxi (reg. no. 61500). United States National Museum, Washington.

2 males, 2 females, c.w. 13.8-18.8 mm, east of Cannery, Juan Fernandez, W. L. Schmitt, December 9, 1926; det. M. J. Rathbun as Cyclograpsus lavauxi (reg. no. 70866 (part)). - United States National Museum, Washington.

Remarks. - There are no important differences between these specimens and those from New Zealand previously reported on by Campbell \& Griffin (1966) except that in the present specimens the lateral margins are very slightly more 

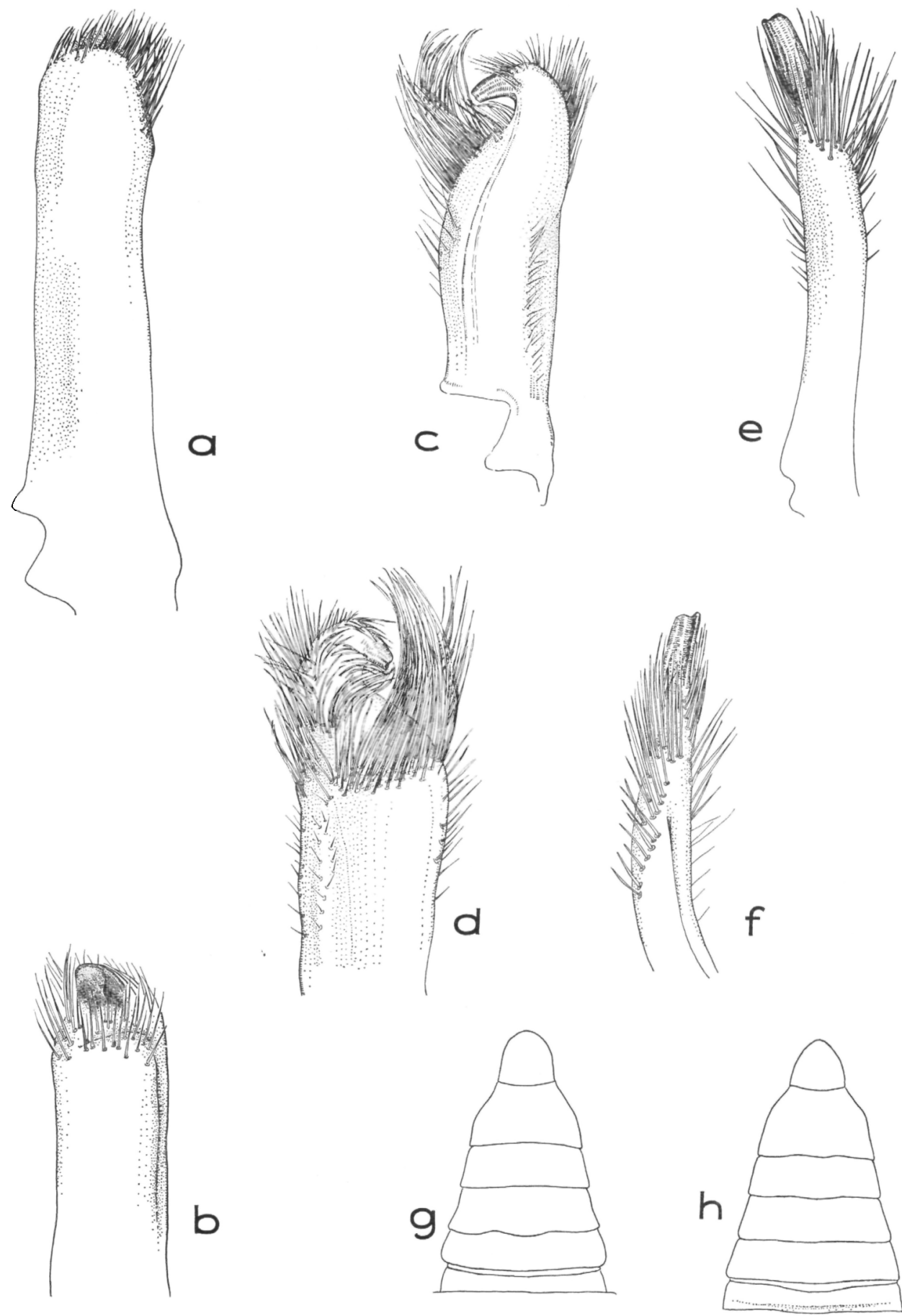

Fig. 4. a-f, male left first pleopod (a, c, e, abdominal face; b, d, f, sternal face); $g, h$, male abdomen. a, b, g, C. sanctaecrucis n. sp.; c, d, C. cinereus Dana; e, f, C. escondidensis Rathbun; h, C. integer H. Milne Edwards. Specimens illustrated same as in fig. 2. 
evenly curved and the propodi in all the ambulatories are a little more stout. The similarity in the pattern of felting on the ambulatories is striking, the only difference being that the bands are a little broader in the present specimens. The Juan Fernandez specimens agree with the New Zealand ones in the shape of the chela in the male except that in some the inner (toothed) edge of the fixed finger is uniformly weakly convex (not concave distally) and the teeth are somewhat more irregular in size; there is a single line of granules along the middle of the inner surface of the hand as is characteristic of this species. The shape of the male abdomen is the same and the details of the pleopod also are the same. The suborbital granules range in number from 10 to 19 with all but two specimens possessing less than 15 (mean 12.4). The two small specimens from the series of 12 collected by Bock and examined previously by Garth (1957) have the posterolateral margins subparallel and the anterolateral parts of the dorsal surface of the carapace and the raised ridge around the margin of the carapace more granular than in most other specimens of this species so far examined.

\section{DISCUSSION}

The present studies bring the total number of species of Cyclograpsus to 16 excluding the so far unidentifiable C. tasmanicus (see Campbell \& Griffin, 1966: 141).

One of the most interesting species of Cyclograpsus is $C$. punctatus. Although this name has been applied in the past to specimens from South Africa, Australia, New Zealand, Chile, Wake Island in the Pacific and from Hong Kong it seems fairly clear now that this species occurs only in South Africa. Cyclograpsus punctatus has been reported from Los Vilos, Valparaiso, Talcahuano and San Vicente on the Chilean mainland by Jacquinot, Nobili, Porter and Rathbun (see Garth, 1957: 101-102). The specimen reported on by Jacquinot (the type of $C$. minutus) is referable to $C$. cinereus (present report) and that discussed by Nobili is apparently no longer in existence (Prof. U. Parenti, Istituto e Museo di Zoologia della Universita di Torino, pers. comm.). This leaves the material in the Valparaiso Museum studied by Porter and Rathbun; the Chilean collection made by Porter prior to 1906 was destroyed by the Valparaiso earthquake and fire of 1906 (see Garth, 1958: 4) and continuing attempts to obtain other material from the Santiago Museum have been unsuccessful. From Juan Fernandez $C$. punctatus was recorded by Lenz and by Garth (see Garth, 1957). Attempts to obtain the material studied by Lenz have also been unsuccessful but that examined by Garth is referable to $C$. lavauxi. However, abundant material of Cyclograpsus from both Chile and Juan Fernandez has been kindly sent to me by Miss Inés Otsu V (Universidad de Chile), Drs. R. B. Manning and H. B. Roberts (U.S. National Museum) and Miss Janet Haig and Dr. J. S. Garth (Allan Hancock Foundation); all specimens from the mainland have been referable to $C$. cinereus and all those from Juan Fernandez have been $C$. lavauxi. Within the context of 
the wide, mainly circumpolar distribution formerly accorded $C$. punctatus, the presence of this species in both South Africa and Chile was quite consistent with what probably exists in other species of similar distribution such as the grapsid crab, Plagusia chabrus (L.). However, with the evidence available showing that Australasian populations of Cyclograpsus are not conspecific with $C$. punctatus the restricted Chilean and South African distribution now allowed this species would almost certainly be unique among the Brachyura. On the other hand, $C$. lavauxi now joins the hymenosomid Halicarcinus planatus and the grapsid Hemigrapsus crenulatus to bring to three the number of brachyurans known only from New Zealand and Chile (including Juan Fernandez). I consider therefore that in the event of future examination of " $C$. punctatus" from Chile the Juan Fernandez specimens will prove to be $C$. lavauxi and the mainland material to be either $C$. cinereus or $C$. lavauxi.

Finally, only the doubtful Hong Kong record by Stimpson (see Campbell \& Griffin, 1966) of C. punctatus remains unconsidered. The bulk of Stimpson's material from the North Pacific Exploring Expedition was destroyed by the Chicago fire of 1871 (see Garth, 1958: 4) and the specimens of "C. punctatus" from Hong Kong are not amongst recently discovered Stimpson material in the British Museum (Natural History) (Dr. A. L. Rice, pers. comm.). It seems not unlikely that Stimpson's material in fact belonged to C. incisus, the only other Cyclograpsus so far known from Hong Kong.

Acknowledgements. - I wish to thank Mr. B. M. Campbell, Queensland Museum (Brisbane) and Dr. J. C. Yaldwyn, Australian Museum (Sydney), for the opportunity to discuss many of the aspects of this study. I am grateful to Drs. R. B. Manning and H. B. Roberts, U.S. National Museum (Washington), Dr. J. S. Garth and Miss Janet Haig, Allan Hancock Foundation (Los Angeles), Drs. W. K. Emerson and A. Ross, American Museum of Natural History (New York), Miss Inés Otsu V, Laboratorio Zoologia, Universidad de Chile (Antofagasta), Mr. H. Petersen, Zoologisches Staatsinstitut und Zoologisches Museum (Hamburg) and Mr. E. H. Bryan Jr., Bernice P. Bishop Museum (Honolulu) for so kindly sending me comparative material from collections in their care; and Mme Danièle Guinot, Muséum National d'Histoire Naturelle (Paris) for sending me photographs of type material. Similarly, I want to thank Dr. L. B. Holthuis, Rijksmuseum van Natuurlijke Historie (Leiden), Dr. A. L. Rice and Mr. R. W. Ingle, British Museum (Natural History), Prof. U. Parenti, Istituto e Museo di Zoologia della Universita di Torino, Prof. E. Tortonese, Museo Civico di Storia Naturale (Genoa), Mr. S. Nunez, Instituto de Investigaciones Marinas, Universidad del Norte (Antofagasta) and Miss Elda Fagetti, Estacion de Biologia Marina, Universidad de Chile (Viña del Mar) for helpful information: and Miss Helen Ashton, Australian Museum, for translating part of the papers by Nobili.

Part of the expenses of these studies was met by a grant from the Australian C S.I.R.O. Science and Industry Endowment Fund. 


\section{RÉSUMÉ}

Une nouvelle espèce du genre Cyclograpsus, C. sanctaecrucis, est décrite des îles de Santa Cruz et Penrhyn (Tongareva) dans l'Océan Pacifique. Elle ressemble à $C$. longipes, $C$. intermedius et C. integer. Cyclograpsus lavauxi, seulement connu jusqu'à présent de la Nouvelle Zélande, est signalé de l'Ile de Juan Fernandez, près de la côte du Chili. L'auteur démontre que C. minutus, décrit par Jacquinot du Chili, est réellement la même espèce que $C$. cinereus; d'autres auteurs ont considéré $C$. minutus comme un synonyme de $C$. punctatus, mais ce dernier est probablement une espèce qui vit seulement en Afrique du Sud et qui n'existe ni au Chili, ni à Juan Fernandez. Des caractères morphologiques d'importance taxonomique, qui n'étaient pas mentionnés précédemment dans la littérature, sont décrits pour $C$. cinereus, $C$. escondidensis et $C$. integer. Le genre $C y c l o-$ grapsus contient dix-sept espèces; l'une d'entre elles, $C$. beccarii, décrite par Nobili de la Nouvelle Guinée occidentale, doit probablement en être exclue.

\section{REFERENCES}

Campbeli, B. M. \& D. J. G. Griffin, 1966. The Australian Sesarminae (Crustacea: Brachyura): genera Helice, Helograpsus nov., Cyclograpsus and Paragrapsus. Mem. Queensland Mus., 14: 127-174, text-figs. 1-10, pls. 20-23.

Crosnier, A., 1965. Crustacés décapodes Grapsidae et Ocypodidae. Faune Madagascar, 18: 1-143, figs. 1-260, pls. 1-11.

EDmondson, C. H., 1925. Marine zoology of the tropical central Pacific. Crustacea. Bull. Bishop Mus. Honolulu, 27: 3-62, figs. 1-8, pls. 1-4.

- 1959. Hawaiian Grapsidae. Occ. Pap. Bishop Mus. Honolulu, 22: 153-202, text-figs. 1-27.

Forest, J. \& DANiÈle Guinot, 1961. Crustacés Décapodes Brachyoures de Tahiti et des Tuamotu. Expédition française sur les técifs coralliens de la Nouvelle-Calédonie, vol. prélim.: i-xi, $1-195$, text-figs. $1-178$, pls. $1-18,1$ map.

- 1962. Rémarques biogéographiques sur les crabes des Archipels de la Société et des Tuamotu. Cah. Pacif., 4: 41-75, 2 tables, 1 fig.

GaRTH, J. S., 1957. The Crustacea Decapoda Brachyura of Chile. Reports of the Lund University Chile Expedition 1948-49. 29. Acta Univ. Lund., (2) 53: 1-127, figs. 1-11, pls. 1-4.

- 1958. Oxyrhyncha. Brachyura of the Pacific coast of America. Allan Hancock Pacif. Exped., 21: i-xii, 1-854, 106 tables, text-figs. 1-9, pls. A-Z, 1-55.

Glassell, S. A., 1933. Descriptions of five new species of Brachyura collected on the west coast of Mexico. Trans. San Diego Soc. nat. Hist., 7: 331-344, pls. 22-26.

Guinot, Danièle \& A. Ribeiro, 1962. Sur une collection de Crustacés Brachyoures des îles du Cap-Vert et de l'Angola. Mem. Junta Invest. ultram., (2) 40: 9-89, figs. 1-33, pls. 1-4.

HartNoll, R. G., 1965. Notes on the marine grapsid crabs of Jamaica. Proc. Linn. Soc. London, 176: $113-147,8$ tables, figs. $1-16$.

Jacquinot, H. \& H. Lucas, 1853. Crustacés. In: Voyage au Pole Sud et dans l'Océanie sur les corvettes l'Astrolabe et la Zelée executé pendant 1837-40, sous le commandement de M. J. Dumont d'Urville, Zoologie, 3: 1-107; atlas (1852), Crustacés: pls. 1-9. (Gide \& Baudry, Paris).

Monod, TH., 1956. Hippidea et Brachyura ouest-Africains. Mém. Inst. Franç. Aft. Noire, 45: $1-674$, figs. $1-884$.

NobiLI, G., 1899. Contribuzioni alla conoscenza della fauna carcinologica della Papuasia, delle Molucche e dell'Australia. Ann. Mus. Civ. Storia nat. Genova, $40(=(2)$ 20) : 229-282.

Tesch, J. J., 1918. Hymenosomidae, Retroplumidae, Ocypodidae, Grapsidae and Gecarcinidae. The Decapoda Brachyura of the Siboga Expedition. I. Siboga Exped. Monogr., 39 (c): 1-148, pls. 1-6.

WARD, M., 1939. The Brachyura of the Second Templeton Crocker-American Museum Expedition to the Pacific Ocean. Amer. Mus. Novit., 1049: 1-15, figs. 1-18. 